\title{
A study on prevalence of ecto- and endo-parasitic infection of cattle at Savar, Dhaka
}

\author{
M.Z. Hassan ${ }^{1 *}$, M.M. Rahman², M.Z. Ali ${ }^{1}$, M.A. Yousuf ${ }^{1}$, M. Hasan ${ }^{1}$, S. Akther ${ }^{3}$, M.H. Rahman ${ }^{3}$, M.A. \\ Islam $^{4}$, A.Hossen ${ }^{5}$ and M.F.R. Mondal ${ }^{6}$
}

${ }^{1}$ Animal Health Research Division, Bangladesh Livestock Research Institute, Savar, Dhaka-1341, Bangladesh. ${ }^{2}$ Conservation and Improvement of Native Sheep Through Community \& Commercial Farming Project, BLRI, Savar, Dhaka-1341. ${ }^{3}$ Goat and Sheep Production Research Division, BLRI, Savar, Dhaka-1341. ${ }^{4}$ Research on FMD and PPR in Bangladesh, BLRI, Savar, Dhaka-1341. System Research Division, BLRI, Savar, Dhaka-1341. ${ }^{6}$ Upazila Livestock Office, Savar, Dept. of Livestock Services, Farmgate, Dhaka.

\begin{abstract}
A prevalence study was conducted to observe both ecto-and endo-parasitic (gastrointestinal) infection throughout one year surveillance. The study was conducted from July 2014 to June 2015 through Parasitology Laboratory, BLRI, Savar, Dhaka. The study considered age of cattle, season and type of parasitic infestation. In the study area total number of cattle population was 2000 in which 500 fecal and 200 ectoparasitic samples was collected considering three respective seasons like rainy, summer and winter. The fecal samples were examined by direct smear method followed by McMaster counting techniques and examine under microscope. After collection of samples within 24 hours all sample were tested by preserving at $4^{0} \mathrm{C}$ temperature. In clinical observation, the overall prevalence of endoparasitic (gastrointestinal) infection was 68\% and ectoparasitic infection was 60\%. Prevalence of endoparasite was more frequent in rainy season $(52.65 \%)$ followed by summer $(27.05 \%)$ and winter season $(20.29 \%)$ whereas prevalence of ectoparasite was more frequent in summer (39\%) followed by rainy (13.5\%) and winter (7.5\%) season. The parasitic prevalence load was low in winter season. In endoparasitic infection, the higher prevalence of Paramphistomum spp. (20\%) was found in rainy season whereas Haemonchus spp. (14\%) and Toxocara spp. (12\%) were higher in summer. In cattle, prevalence of Paramphistomum spp. (25.14\%) and Haemonchus spp. (18.58\%) was higher in adult cattle (above 6 months), whereas prevalence of Toxocara spp. (36.67\%) and Coccidial oocyst (23.33\%) was higher in calf (under 6 month) than adult animal (above 6 months) of age. The overall prevalence of ectoparasite was $60 \%$ and tick infestation was highest (22.5\%) followed by lice (17.5\%), mange $(12.5 \%)$ and maggot fly $(7.5 \%)$. High humidity (above 70\%) and temperature provoke high endo- and ecto-parasite infection in the environment and infect cattle as well as other livestock species.
\end{abstract}

(Key words: Cattle, ectoparasite, endoparasite, prevalence, seasons)

\section{Introduction}

Bangladesh is an agricultural country where $21 \%$ GDP comes from the agricultural sector like crops, livestock, fisheries and forestry. There are about 23.63 million cattle, 1.46 million buffalo, 3.27 million sheep and 25.6 million goat populations in Bangladesh. So total ruminant population was 53.97 million. In case of poultry, there are 261.77 million chickens and 50.52 million duck population exist in Bangladesh. So, the total poultry population was 312.29 million and the total livestock population was 366.26 million in Bangladesh. Livestock contributing about $1.73 \%$ in GDP and growth rate of GDP was

*Corresponding author: zakir.vet@blri.gov.bd

Bang. J. Livs. Res. Special Vol. 21-25, 2018: P. 29-35, ISSN 1022-3851 
$3.10 \%$. The employment status on livestock is $20 \%$ directly, $50 \%$ partially; cultivation of land by livestock $50 \%$ and fuel supply from livestock and poultry $25 \%$. Livestock also share in agricultural GDP $14.21 \%$. (Livestock Economy, 2017-18). In 2014-15 there are about 2000 core $\mathrm{Tk}$ foreign currency earn from exporting livestock product and by product. There are about $20 \%$ production losses due to animal diseases worldwide, but in Bangladesh production losses up to $35-50 \%$. Parasitism claims to be one of the main obstacles in livestock rearing in Bangladesh (Jabbar et al., 1983; Khokan et al., 2017). The hot humid climatic condition in Bangladesh greatly favors the development and survival of ecto- and endoparasite that makes violence of parasitism. Parasitic diseases are of great economic importance in livestock (Islam, 1985). Asian Development Bank (1984) estimated the loss of productivity of animals in terms of mortality, loss of milk and meat, generation loss and loss of reproductive rate due to animal parasites to the extent of $50 \%$ in Bangladesh. Gastrointestinal (GI) parasitic infections may be considered as one of the major constraints in cattle production. The infection causes productivity losses through reduced feed intake and decreased efficiency in feed utilization due to subclinical or chronic infections that are responsible for economic losses (Renaldi et al., 2011; Bary et al., 2018). In Bangladesh, disease problems specially related to parasitism constitute a serious threat. Gastrointestinal parasitism is a world-wide problem (Regassa et al., 2006). Parasitism is one of the major constraints that hinder the development of livestock population and also adversely affects the health and productivity of animals (Kakar et al., 2008; Radostits et al., 1994). The losses caused by parasitic infections are in the form of lowered general health condition, retarded growth rate, diminishing the working efficiency, decrease milk and meat production, abortion; cost associated with preventive measures and reduces the disease resistance capability, which may ultimately lead to higher mortality (Silvestre et al., 2000). Parasitic problems are often neglected and overlooked as majority of the infected animals show a number of little obvious clinical signs during their productive life and their effects are gradual and chronic (Raza et al., 2010). Therefore, the objective of this study was to investigate the prevalence of ecto- and endo- parasitic diseases in selected area of Savar upazila, Dhaka.

\section{Materials and Methods}

\section{Study Area}

The study was conducted from June 2014 to July 2015 through Parasitology Laboratory, Animal Health Research Division (AHRD), Bangladesh Livestock Research Institute (BLRI), Savar, Dhaka. Hence five corresponding village like Jalessore, Jamsing, Vatpara, Pathalia and Kuturia under Savar Upazila, Dhaka was considered for these study. A total cattle population was about 2000 and 500 fecal and 200 ectoparasitic samples through hand picking were collected under three consecutive seasons like rainy, summer and winter. Here, up to six months was considered as calf and above 6 month to 4 year was considered as adult in this study.

\section{Sample collection}

During sample collection particular data of the animals like, breed, age, sex and general body condition was recorded. Faecal samples (approximately $5 \mathrm{gm}$ ) were collected directly 
from the rectum of the cattle and put into small plastic containers, and stored in ice containing cool box and also labeled the sample properly. The samples were immediately transferred to the Parasitology Laboratory, AHRD, BLRI and stored at $4{ }^{\circ} \mathrm{C}$ temperature until further examination. Both the direct smear and McMaster technique was done described by Urquhart et al., (1996) were performed to screen out the positive samples. Ectoparasites were collected from the different parts of the body of the individual cattle by hand picking. When required ethanol dipped hair brush was used for the collection of ticks. The point of attachment was smeared with ethanol. Adequate precautions were taken to preserve the mouthparts and appendages of the ectoparasites during collection. Ectoparasites were preserved in $70 \%$ alcohol in clean and well stopper glass vials which were labeled properly.

\section{Laboratory examination of fecal sample}

For McMaster counting technique super saturated flotation fluid was prepared through mixing 400g Sodium Chloride $(\mathrm{NaCl})$ with $1000 \mathrm{ml}$ of tap water. In case of direct smear, small amount of fresh fecal sample (1 drop) was mixed with 1 to 2 drop of tap water thoroughly in a glass slide and large and worse particle were avoided by a cotton strip. Covered the smear was done with cover slip and examination was done under microscope at $10 \times$ objective and also gone through $40 \times$ objective. In case of McMaster technique, $3 \mathrm{gm}$ homogenized fresh fecal sample mixed with $42 \mathrm{ml}$ of super saturated floatation fluid and double sieved filtration was done. This solution was remaining for 30-40 minutes in a glass beaker.
After that, supernatant fluid was dispensed in MacMaster slide, both two chamber were examined under microscope at $10 \times$ objective. Identification was done and calculated total number of parasitic egg as Egg per Gram of Faces (EPG) by multiplying total number of parasitic egg of two chambers with 50 . Parasitic load was graded as 1 to 500 as mild, above 500 to 750 as moderate and above 750 considered as severe infection (Sweeny et al., 2011).

\section{Results}

The overall prevalence of endoparasitic infection was $68 \%$, where 340 fecal samples were positive out of 500 representative fecal samples (Table 1). In Savar Upazila, prevalence of Paramphistomum spp. was $20 \%$ and Haemonchus spp. was $14 \%$ followed by Toxocara spp. $12 \%$ and Cocidial oocyst $8 \%$ (Table 1). In cattle prevalence of Paramphistomum spp. was $25.14 \%$ and Haemonchus spp. was $8.58 \%$ that was higher in adult cattle (above 6 month), whereas prevalence of Toxocara spp. was $36.67 \%$ and Coccidial oocyst was $23.33 \%$ that was higher in calf (under 6 month) than adult (Table 2). For comparing the three seasons, the highest endoparasitic infestation occurred in rainy season $(52.65 \%)$ where summer and winter season showed (27.05\%) and (20.29\%). Here, there was highest prevalence of Paramphistomum spp. (14.78\%) in rainy season followed by summer $(8.83 \%)$ and winter season $(5.88 \%)$. In case of winter season the highest prevalence of Schistosoma spp was $4.41 \%$ and Paramphistomum spp. was $5.88 \%$ (Table 3). The overall prevalence of ectoparasites was $60 \%$ and tick infestation was the highest $(22.5 \%)$ followed by lice (17.5\%), mange 
$(12.5 \%)$ and maggot fly $(7.5 \%)$ (Table 4$)$. The prevalence of ectoparasites was the highest in summer season (39\%) followed by rainy $(13.5 \%)$ and winter season $(7.5 \%)$ (Table 4$)$.

Table1. Prevalence of endo-parasite of cattle according to parasitic species

\begin{tabular}{clcc}
\hline SL No. & \multicolumn{1}{c}{ Parasitic spp } & $\begin{array}{c}\text { Number of } \\
\text { infection }(\mathrm{n}=500)\end{array}$ & Prevalence \\
\hline 1. & Paramphistomum spp. & 100 & $20 \%$ \\
2. & Fasciola spp. & 20 & $4 \%$ \\
3. & Haemonchus spp. & 70 & $14 \%$ \\
4. & Toxocara spp. & 60 & $12 \%$ \\
5. & Coccidial oocyst & 40 & $8 \%$ \\
6. & Schistosoma spp. & 20 & $4 \%$ \\
7. & Fasciola spp. + Paramphistomum spp. & 20 & $4 \%$ \\
8. & Toxocara spp. + Coccidial oocyst & 10 & $2 \%$ \\
\hline \multicolumn{5}{c}{ Oveall Prevalence } & $(\mathrm{N}=500)$ & 340 & $68 \%$ \\
\hline
\end{tabular}

Table 2. Prevalence of endoparasite in Savar according to age of cattle

\begin{tabular}{|c|c|c|c|c|c|}
\hline $\begin{array}{l}\text { SL } \\
\text { No. }\end{array}$ & Parasitic spp & $\begin{array}{l}\text { Number of } \\
\text { infection } \\
\text { in adult } \\
\text { cattle } \\
(\mathrm{n}=350)\end{array}$ & $\begin{array}{l}\text { Prevalence } \\
(\mathrm{n}=350)\end{array}$ & $\begin{array}{l}\text { Number of } \\
\text { infection in calf } \\
(\mathrm{n}=150)\end{array}$ & $\begin{array}{l}\text { Prevalence } \\
(n=150)\end{array}$ \\
\hline 1 & Paramphistomum spp. & 88 & $25.14 \%$ & 12 & $8 \%$ \\
\hline 2 & Fasciola spp. & 18 & $5.14 \%$ & 2 & $1.33 \%$ \\
\hline 3 & Haemonchus spp. & 65 & $18.58 \%$ & 5 & $3.33 \%$ \\
\hline 4 & Toxocara spp. & 5 & $1.42 \%$ & 55 & $36.67 \%$ \\
\hline 5 & Coccidial oocyst & 5 & $1.42 \%$ & 35 & $23.33 \%$ \\
\hline 6 & Schistosoma spp. & 18 & $5.14 \%$ & 2 & $1.33 \%$ \\
\hline \multirow[t]{2}{*}{7} & Fasciola spp. ${ }^{+}$ & 18 & $5.14 \%$ & 2 & $1.33 \%$ \\
\hline & Paramphistomum spp. & & & & \\
\hline \multirow[t]{2}{*}{8} & $\begin{array}{l}\text { Toxocara spp. }+ \\
\text { Coccidial oocyst }\end{array}$ & 2 & $0.58 \%$ & 8 & $5.33 \%$ \\
\hline & Total Prevalence & 219 & $62.57 \%$ & 121 & $80.65 \%$ \\
\hline
\end{tabular}


Table 3.Prevalence of endoparasite according to season

\begin{tabular}{|c|c|c|c|c|c|}
\hline \multirow{2}{*}{$\begin{array}{l}\text { SL } \\
\text { No. }\end{array}$} & \multirow[t]{2}{*}{ Parasitics pecies } & \multirow{2}{*}{$\begin{array}{l}\text { Number of } \\
\text { infection } \\
(\mathrm{n}=500)\end{array}$} & \multicolumn{3}{|c|}{ Season } \\
\hline & & & Rainy & Summer & Winter \\
\hline 1. & Paramphistomum spp. & 100 & $50(14.78 \%)$ & $30(8.83 \%)$ & $20(5.88 \%)$ \\
\hline 2. & Fasciola spp. & 20 & $10(2.94 \%)$ & $5(1.47 \%)$ & $5(1.47 \%)$ \\
\hline 3. & Haemonchus spp. & 70 & $40(11.76 \%)$ & $20(5.88 \%)$ & $10(2.95 \%)$ \\
\hline 4. & Toxocara spp. & 60 & $25(10.3 \%)$ & $15(4.41 \%)$ & $10(2.95 \%)$ \\
\hline 5. & Coccidial Oocyst & 40 & $20(5.89 \%)$ & $15(4.41 \%)$ & $5(1.47 \%)$ \\
\hline 6. & Schistosoma spp. & 20 & $3(0.89 \%$ & $2(0.58 \%)$ & $15(4.41 \%)$ \\
\hline \multirow[t]{2}{*}{7.} & Fasciola spp.+ & 20 & $15(4.41 \%)$ & $3(0.89 \%)$ & $2(0.58 \%)$ \\
\hline & Paramphistomum spp. & & & & \\
\hline \multirow[t]{3}{*}{8.} & Toxocara spp.+ & 10 & $6(1.76 \%$ & $2(0.58 \%)$ & $2(0.58 \%)$ \\
\hline & Coccidial Oocyst & & & & \\
\hline & Total positive sample & 340 & $179(52.65 \%)$ & $92(27.05 \%)$ & $69(20.29 \%)$ \\
\hline
\end{tabular}

Table 4. Prevalence of ectoparasite species in cattle in Savar

\begin{tabular}{ccccccc}
\hline SL No. & $\begin{array}{c}\text { Type of } \\
\text { infestation } \\
(\mathrm{n}=200)\end{array}$ & $\begin{array}{c}\text { Positive } \\
\text { number of } \\
\text { infestation }\end{array}$ & Prevalence & \multicolumn{3}{c}{ Season } \\
\cline { 3 - 6 } & Tick & 45 & $22.5 \%$ & $8(4 \%)$ & $32(16 \%)$ & $5(2.5 \%)$ \\
\hline 1. & 35 & $17.5 \%$ & $8(4 \%$ & $24(12 \%)$ & $3(1.5 \%)$ \\
2. & Lice & 25 & $12.5 \%$ & $7(3.5 \%)$ & $14(7 \%)$ & $4(2 \%)$ \\
3. & Mange & 15 & $7.5 \%$ & $4(2 \%)$ & $8(4 \%)$ & $3(1.5 \%)$ \\
4. & Maggot fly & 120 & $60 \%$ & $27(13.5 \%)$ & $78(39 \%)$ & $15(7.5 \%)$ \\
\hline & Total & & & & & \\
\hline
\end{tabular}

\section{Discussion}

The prevalence of Paramphistomum spp. was higher in adult cattle (20\%) and Toxocara spp. in calf that strongly supported the observation of Akanda et al. (2014) where the result implies that higher prevalence of Paramphistomum spp. in adult and Toxocara spp. in calf. Paramphistomum spp., Fasciola spp., Haemonchus spp. were found more in adult cattle that supported the observation of Sardar et al., (2006), where the report stated that Paramphistomum spp., Fasciola spp., Haemonchus spp. were found more in adult animal than young. The prevalence of Toxocara spp. (12\%) followed by Coccidial oocyst ( $8 \%$ ) that support the report of Bachal et al. (2002), where reported that such type of 
infection was found in early in life of animal. Higher prevalence of parasitic infection was found in adult cattle due to longer period of production time (Sardar et al., 2006). Animal stress condition like lactation, pregnancy, malnutrition also accounted for higher prevalence of parasitic infection (Radostits et al.,1994). The prevalence more in rainy season $(52.65 \%)$ followed by summer $(27.05 \%)$ and winter season $(20.29 \%)$ that also due to adequate moisture and optimum temperature favored the growth and survival of parasitic infective stage, which was strongly supported the findings of Shiale et al. (2008) where stated that gastrointestinal parasitism were observed more in rainy season followed by summer and winter season. Hot humid climate in summer and low temperature in winter season provides unfavorable condition of parasitic growth and development (Pfukenyi et al., 2007). The overall prevalence of ectoparasites was $60 \%$ and highest prevalence was tick infestation $(22.5 \%)$ followed by lice $(17.5 \%)$ and mange $(12.5 \%)$, that was compared the prevalence rate of Rahman et al. (2012). The prevalence of ectoparasites was higher in summer season $(39 \%)$ followed by rainy $(13.5 \%)$ and winter season $(7.5 \%)$. This result also favors Islam et al. (1985), where stated that hot humid climatic condition in Bangladesh greatly favors the development and survivability ecto- and endo- parasite and makes violence of parasitism.

\section{Conclusion}

This surveillance work gives an outline about endo- and ecto-parasitic infestation in Savar, Dhaka that will be helpful to design a layout for controlling parasitic infestation in this area.

\section{References}

Akanda, M.R.,Hasan, M.M.I., Belal, S.A., Roy, A.C., Ahmad, S.U., Das, R. and Masud, A,A. 2014. A Survey on Prevalence of Gastrointestinal Parasitic Infection in Cattle of Sylhet Division in Bangladesh. American Journal of Phytomedicine and Clinical Therapeutics. 2(7): 855-860

Asian Development Bank (ADB). 1984. Asian development bank yearbook.

Bachal, B., Phullan, M.S., Rind, R., Soomro, A.H. 2002. Prevalence of Gastrointestinal Helminths in Buffalo Calves. Journal of Biological Sciences. 2(1):43-45

Bary, M.A., Ali, M.Z., Chowdhury, S., Mannan, A., Azam, M.N.E., Moula, M.M., Bhuiyan Z.A., Shaon, M.T.W., Hossain, M.A. 2018. Prevalence and Molecular Identification of Haemoprotozoan Diseases of Cattle in Bangladesh. Advances in Animal and Veterinary Sciences. 6(4): 176-182

Belem, A.M.G., Ouedraogo. O.P., Rene.Bessin, R., 2001. Gastro-intestinal nematodes and cestodes of cattle in Burkina Faso. Biotechnologie, Agronomie, Sociétéet Environnement. 5: 17-21

Blood, D.C. and Radostits, O.M. 1989. Veterinary Medicine .7th edn. Balliere and Tindal, London.

Islam, K.S.1985. Present situation of livestock and poultry diseases in Bangladesh. In: Jabbar MA (ed) Bangladesh poshusampadunnayunNeeti O Kowshal BARC, Dhaka and ADC NY: 84-128.

Jabbar, M. and Green, D.A.G. 1983. The status and potential of livestock within the context of agricultural development policy in Bangladesh, The University of Wales, Aberyswyth, UK, p. 113.

Kakar, M.N., Kakarsulemankhel, J.K. 2008. Prevalence of endo (trematodes) and ectoparasites in cows and buffaloes of Quetta, Pakistan. Pakistan Veterinary Journal. 28(1): 34-36. 
Khokon, M.S.I., Azizunnesa, M., Islam, M.M., Chowdhury, K.B., Rahman, M.L. and Ali, M.Z. 2017. Effect of mastitis on post-partum conception of crossbred dairy cows in Chittagong district of Bangladesh. Journal of Advanced Veterinary and Animal Research. 4(2): 155-160.

Livestock Economy, DLS. BD. 2017-18. www. dls.gov.bd

Pfukenyi, D.M., Mukaratirwa, S., Monrad, J. 2007. Epidemiological studies of parasitic gastrointestinal nematodes, cestodes and coccidian infections in cattle in the Highveld and lowveld communal grazing areas of Zimbabwe. Onderstepoort Journal Veterinary Research. 74: 129-142.

Radostits, O., Blood, D.C., Gay, C.C. 1994. Veterinary Medicine: A text book of disease of cattle, sheep, pigs, goats and horse. 8th ed. Baillere Tindall Publication, London, 12231225, 1237-1238

Rahman, M.A., Islam, M.A., Talukder, A.K., Parvin, M.S., and Islam, M.T. 2012. Clinical disease of ruminant recorded at the Patuakhali Science and Technology University Veterinary clinic. Bangladesh Journal of Veterinary Medicine. 10 (1\&2): 63-73

Raza, A.M., Murtaza, S., Bachaya, H.A., Qayyum, A., Zaman, M.A. 2010. Point Prevalence of Toxocaravitulorum in Large Ruminants Slaughtered at Multan Abattoir. Pakistan Veterinary Journal. 30(4), 242- 244

Regassa, F., Sori, T., Dhuguma, R., Kiros, Y., 2006. Epidemiology of Gastrointestinal Parasites of Ruminants in Western Oromia, Ethiopia. International Journal of Applied Research in Veterinary Medicine. 4(1): 51-57

Rinaldi, M., Dreesen, L., Hoorens, L., Li, P.R., Claerebout, R.W., Goddeeris, E., Vercruvsse, B. J., Van, Den Broek, Geldhof, P. 2011. Infection with gastrointestinal nematode Ostertagia ostertagi in cattle affects mucus biosysthesis in the abomasums. Veterinary Research. 42: 61
Sardar, S.A., Ehsan, M.A., Anower, A.K.M.M., Rahman, M.M., Islam, M.A.2006. Incidence of liver flukes and gastro-intestinal parasites in cattle. Bangladesh Journal of Veterinary Medicine. 4 (1): 39-42

Shirale, S.Y., Meshram, M.D., Khillare, K.P. 2008. Prevalence of gastrointestinal parasites in cattle of Western Vidarbha Region. Veterinary World. 1(2): 45

Silvestre, A., Chartier, C., Sauve, C., Cabaret, J. 2000. Relationship between helminth species diversity, intensity of infection and breeding management in dairy goats. Veterinary Parasitology. 94: 91-105

Sweeny, J.P.A., Robertson, I.D., Ryan, U.M., Jacobson, C., Woodgate, R.G. 2011. Comparison of molecular and McMaster microscopy techniques to confirm the presence of naturally acquired strongylid nematode infections in sheep. Molecular and Biochemical Parasitology. 180(1):62-67

Urquhart, G.M., Armour, J., Duncan, J.L, Dunn, A.M. and Gennings, F.W. 1996. Veterinary Parasitology 2nd edn. Blackwell Science Ltd. UK, pp170-176

Wall, R. and Shearer, D. 1997. Veterinary Entomology, 1st edition, Chapman and Hall. London, UK. pp 265 and 290 